\title{
Investigating daytime and night-time differences with the seasonal trend and sources of inorganic fine aerosols in Indo-Gangetic plain
}

\author{
S Chandra ${ }^{1,3}$, M J Kulshrestha ${ }^{1, *}$, B Kumar ${ }^{2}$ and R K Kotnala ${ }^{1}$ \\ ${ }^{1}$ CSIR-National Physical Laboratory, New Delhi 110 012, India. \\ 2 Jawaharlal Nehru University, New Delhi 110 067, India. \\ ${ }^{3}$ Present address: Vivekananda College, University of Delhi, Delhi 110 095, India. \\ *Corresponding author. e-mail: monikajk@yahoo.com
}

MS received 14 September 2017; revised 6 May 2018; accepted 9 May 2018;

published online 1 February 2019

This study investigates the seasonal distribution of inorganic aerosols in Central New Delhi and identifies their potential source regions using concentration weighted trajectories (CWTs). Secondary inorganic aerosols $\left(\mathrm{NO}_{3}^{-}, \mathrm{SO}_{4}^{2-}, \mathrm{NH}_{4}^{+}\right)$are the largest contributors to fine particulate matter in New Delhi, India. The concentrations of secondary inorganic aerosols showed very distinct seasonal patterns with higher concentrations in winter and post-monsoon seasons. Inorganic ions $\mathrm{Ca}^{2+}, \mathrm{Mg}^{2+}$ and $\mathrm{K}^{+}$were also examined to understand their temporal trends. The primary aerosols were found to have smaller diurnal differences than secondary aerosols. The higher coefficient of divergence for secondary aerosols indicated a significant difference in their chemistry and/or meteorology during daytime and night-time, respectively. The backward trajectory analysis revealed the advection of ionic species from distant sources responsible for their significant seasonality. The highest concentrations of $\mathrm{K}^{+}$during the post-monsoon season were mainly influenced by air masses arriving from Punjab and Haryana regions resulting from the prominent agricultural crop residue burning in these areas. CWT also identified the Thar Desert and Punjab as potential regions for enhanced levels of $\mathrm{Ca}^{2+}$ and $\mathrm{K}^{+}$, respectively. Also, the brick kilns located in western UP were observed as the major potential sources for $\mathrm{NO}_{3}^{-}$and $\mathrm{SO}_{4}^{2-}$.

Keywords. $\mathrm{PM}_{2.5}$; water-soluble inorganic species; secondary aerosols; coefficient of divergence; concentration weighted trajectory.

\section{Introduction}

The global mean aerosol burden of the atmosphere has significantly increased due to continuously increasing emissions from various anthropogenic activities such as industries, automobile vehicles and infrastructure buildings (Echalar et al.
1998; Kim et al. 2003; Ragosta et al. 2008; Righi et al. 2013). This has significantly affected the air quality, visibility, atmospheric composition, ecosystem and earth's radiation budget (Pope 2000; Hong et al. 2002; IPCC 2007). The combustion processes including automobile exhaust are well known to contribute to fine aerosols directly or through

Supplementary material pertaining to this article is available on the Journal of Earth System Science website (http://www. ias.ac.in/Journals/Journal_of_Earth_System_Science). 
the gas-to-particle conversion process (Jonathan et al. 1997). Fine mode aerosols further interact with atmospheric gaseous and secondary species resulting in the change in their chemical composition (Kumar and Sarin 2009). For example, $\mathrm{NO}_{x}$ oxidation leads to the formation of $\mathrm{NO}_{3}^{-}$ (Wang et al. 2006) which later on reacts with $\mathrm{NH}_{3}$ present in the atmosphere forming $\mathrm{NH}_{4} \mathrm{NO}_{3}$ aerosols (Utsunomiya and Shinji 1996). Further, $\mathrm{NO}_{3}^{-}$formation during day hours facilitates the production of secondary organic aerosols enhancing their hygroscopic nature thereby affecting the scattering properties of the atmosphere, thus reducing the visibility (Malm et al. 1996; Brown et al. 2006). Oxidation of $\mathrm{SO}_{2}$ results in the formation of $\mathrm{H}_{2} \mathrm{SO}_{4}$, which further reacts with atmospheric $\mathrm{NH}_{3}$ forming particles like $\left(\mathrm{NH}_{4}\right)_{2} \mathrm{SO}_{4}$ and $\left(\mathrm{NH}_{4}\right) \mathrm{HSO}_{4}$ (Finlayson-Pitts and Pitts 2000). Hence, $\mathrm{NO}_{3}^{-}$, $\mathrm{SO}_{4}^{2-}$ and $\mathrm{NH}_{4}^{+}$are considered as the secondary aerosols mainly contributed by pollution sources (Malm et al. 1996; Cheung et al. 2005). These ionic species constitute a significant fraction of fine aerosols (Karageorgos and Rapsomanikis 2007). The formation of secondary aerosols from preexisted particles of primary origin has also been acknowledged as the main cause of the air pollution over mega-cities (Lee and Sequeira 2002; Dall'Osto et al. 2009; Guo et al. 2010; Zhang et al. 2010; Cheng et al. 2015).

New Delhi is rapidly becoming one of the most polluted cities in the world (WHO 2014) and the impact of particulate matter (PM) pollution is currently a major concern for the public health of the community in New Delhi (Kesavachandran et al. 2015). Secondary inorganics along with carbonaceous matter are the major components that need to be controlled to reduce particulate pollution in New Delhi (Bisht et al. 2015). There are a number of recent studies focusing on the sources and trends of carbonaceous aerosols in New Delhi (Miyazaki et al. 2009; Srivastava et al. 2014; Kumar et al. 2015) while less efforts have been made on the sources of fine inorganic aerosols (Bisht et al. 2015). Most of the earlier studies have reported water-soluble ions in TSPM, SPM or $\mathrm{PM}_{10}$ aerosols for selected cities such as Agra (Kulshrestha et al. 1998, 2009a), Kanpur (Ram and Sarin 2011) and Raipur (Deshmukh et al. 2010). The city such as Delhi, where population density is one of the highest compared to all other Indian States or Union Territories $\left(11,297 / \mathrm{km}^{2}\right.$ according to 2011 Census), needs to be addressed for fine aerosols. In this paper, we report the daytime and night-time seasonal variability of secondary and primary inorganic ionic species in $\mathrm{PM}_{2.5}$. Also, we explore the potential source regions these components using concentration weighted trajectory (CWT).

\section{Method and materials}

\subsection{Study site}

$\mathrm{PM}_{2.5}$ samples were collected at the National Physical Laboratory India (NPLI) located in central Delhi $\left(28^{\circ} 38^{\prime} \mathrm{N}\right.$ and $77^{\circ} 12^{\prime} \mathrm{E}, 283 \mathrm{~m}$ above sea level) (figure 1). The NPL campus is surrounded by the farms of Indian Agricultural Research Institute ( $\sim 500$ ha), Central Delhi ridge ( $~ 864$ ha forest cover), commercial and residential areas. About 8000 factories are registered in the city, e.g., 1759 metal, 293 chemical products, 557 rubber/plastic and 279 leather factories (Economy Survey of Delhi, 2012-2013). Besides, 7.4 million motor vehicles are registered in the city. Major air pollution sources include automobile transport and industries.

\subsection{Sample collection}

The sample collection was carried out during the year 2011 at the terrace of the NPL building at a height of $\sim 15 \mathrm{~m}$ above the ground level. $\mathrm{PM}_{2.5}$ samples were collected on $47 \mathrm{~mm}$ quartz filters (Whatman) by using a low-volume sampler operated at an average flow rate of $1 \mathrm{~m}^{3} / \mathrm{hr}$. The samples were collected at $12 \mathrm{~h}$ interval (daytime and night-time basis) for $\sim 5$ days ( $\sim 10$ samples and one field blank) every month during the year 2011. A total of 118 samples (winter, $n=36$; summer, $n=46$; monsoon, $n=22$; post-monsoon, $n=14$ ) were collected during the study period. The collected samples were stored in pre-cleaned polypropylene Petri-dishes and refrigerated at $0^{\circ} \mathrm{C}$. The blanks were also processed in the same manner as the actual samples.

\subsection{Sample analysis}

A $0.5 \mathrm{~cm}^{2}$ circular piece was cut from the collected filter of each sample and extracted into 10 $\mathrm{ml}$ ultrapure water (Millipore, specific resistance: $18.2 \mathrm{M} \Omega \mathrm{cm}$ ) for $75 \mathrm{~min}$ by using an ultrasonic bath (the water was replaced every $20 \mathrm{~min}$ to avoid extra heating of samples). The solution was filtered through a micro-porous membrane filter 

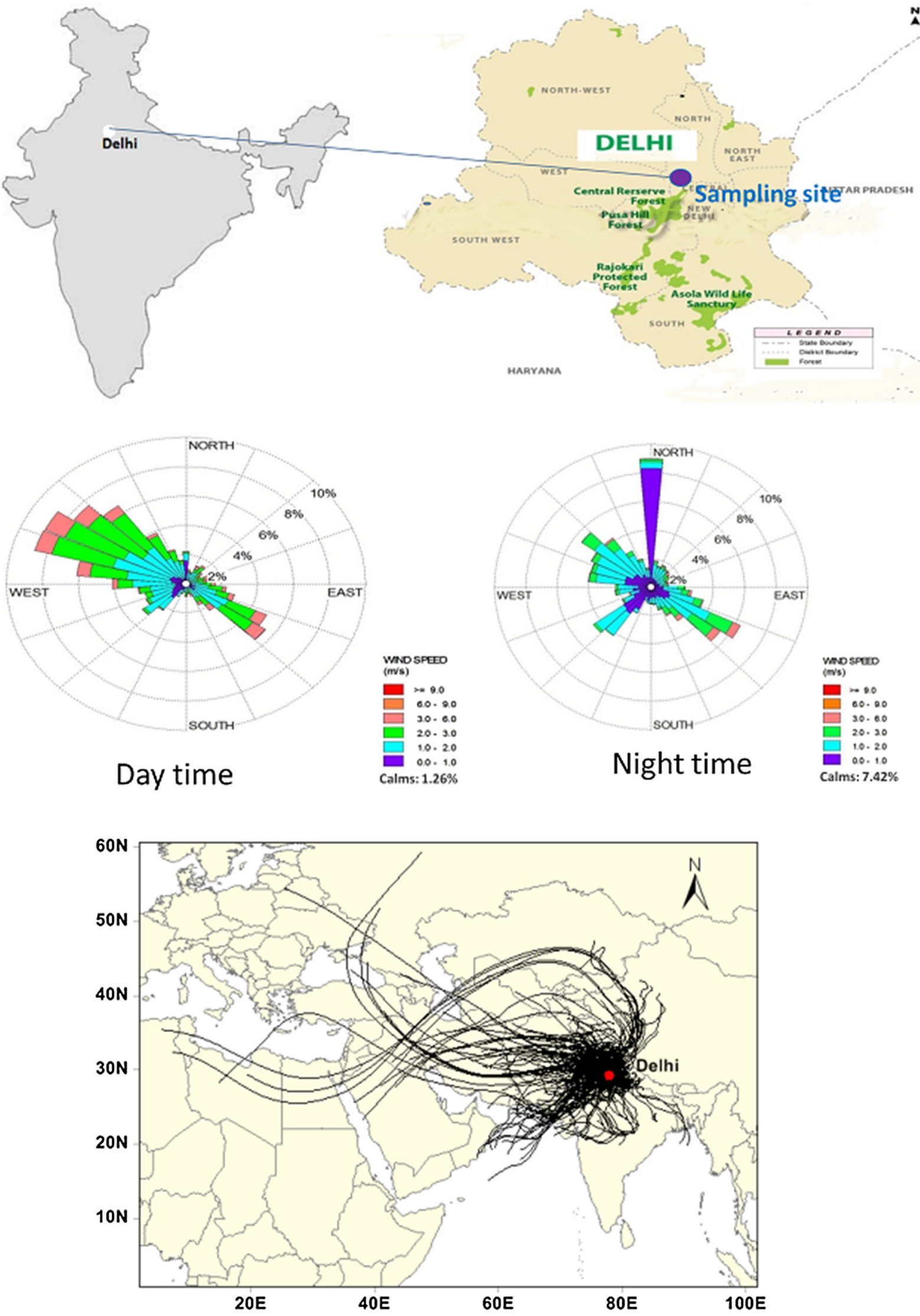

Figure 1. Location of sampling site, prevailing wind pattern and trajectory map (not to scale). 
(PALL, Ultipor $\mathrm{N}$ Nylon 6, 6-membrane, pore size $0.45 \mu \mathrm{m}$, diameter $25 \mathrm{~mm}$ ). The extracted samples were stored in a refrigerator at $0^{\circ} \mathrm{C}$ until the further chemical analysis. Repeated extraction of the same filter provided extraction efficiency of $\sim 99.9 \%$. The ion chromatograph (Metrohm 883) was used to measure water-soluble ionic species $\left(\mathrm{NH}_{4}^{+}, \mathrm{K}^{+}, \mathrm{Mg}^{2+}, \mathrm{Ca}^{2+}, \mathrm{NO}_{3}^{-}\right.$and $\left.\mathrm{SO}_{4}^{2-}\right)$ in the aqueous extract of samples. The determination of these ions was done by using separation columns (Metrosep C2-100 and Metrosep A supp 5-100) for cations and anions, respectively. For cations, a mixture of $4.0 \mathrm{mM}$ tartaric acid and $0.75 \mathrm{mM}$ 2, 6-pyridine dicarboxylic acid at a flow rate of 1.0 $\mathrm{ml} / \mathrm{min}$ was used as eluent. While for anions, a mixture of $3.2 \mathrm{mM} \mathrm{Na}_{2} \mathrm{CO}_{3}$ and $1.0 \mathrm{mM} \mathrm{NaHCO}_{3}$ was used at a flow rate of $1.0 \mathrm{ml} / \mathrm{min}$ with Metrohm suppressor technique. The standards of known concentrations were used for making three-point calibration curves $\left(R^{2}=1\right.$ for all ions with maximum RSD within 2.5\%). The standards (Merck) used for cations $\left(\mathrm{NH}_{4}^{+}, \mathrm{K}^{+}, \mathrm{Ca}^{2+}\right.$ and $\left.\mathrm{Mg}^{2+}\right)$ were 2, 5 and $10 \mathrm{ppm}$ while 1,2 and $5 \mathrm{ppm}$ for anions. The per cent relative standard deviation for samples was within $7 \%$ as measured by analysing a set of five replicate samples for all major ions. The blank filters were also analysed and the concentrations of all the major ionic species were noted below the detection limit (the detection limits for $\mathrm{SO}_{4}^{2-}, \mathrm{NO}_{3}^{-}, \mathrm{NH}_{4}^{+}, \mathrm{K}^{+} \mathrm{Ca}^{2+}$ and $\mathrm{Mg}^{2+}$ for the instrument were $5,5,2,5,10$ and $5 \mathrm{ppb}$, respectively).

\subsection{Meteorology in Delhi}

The Delhi region experiences four distinct seasons, viz., summer (March-June), monsoon (JulySeptember), post-monsoon (October-November) and winter (December-February) in a year. Frequent dust storms are observed during the summer season. Monsoon season is known for maximum rainfall ( $\sim 90 \%)$ followed by the post-monsoon season having moderate weather conditions. Winter season is observed with low temperature and calm wind conditions. The wind patterns showed more frequent calm conditions during night-time as compared to daytime (figure 1). The mixing height during daytime was observed to be higher as compared to night-time (figure 2). The annual mean of mixing heights for daytime and night-time was calculated as 984 and $147 \mathrm{~m}$, respectively (using data from http://ready.arl.noaa.gov/READYamet. php).

\section{Data analysis}

\subsection{Coefficient of divergence (COD)}

The COD was used to provide information on the degree of uniformity between day and night at the sampling site:

$$
\operatorname{COD}_{f h}=\sqrt{\frac{1}{P} \sum_{l=1}^{p}\left(\frac{x_{i f}-x_{i h}}{x_{i f}+x_{i h}}\right)^{2}},
$$

where $x_{i f}$ is the $i$ th hourly averaged concentration at a given size interval measured at two different times, $f$ and $h$ are two different times, and $p$ is the number of observations (Wilson et al. 2005).

\subsection{Concentration weighted trajectory}

The CWT analysis was done using TrajStat: GISbased software (http://www.meteothinker.com/ Documents/Wang_Trajstat_Manuscript.pdf) to estimate the local vs. regional contribution to inorganic ions in $\mathrm{PM}_{2.5}$ at the receptor site. CWT is a type of hybrid receptor model used in the study of pollutants transport by using isentropic backward air trajectory and their estimated concentrations (Beegum et al. 2012; Cheng et al. 2013). This approach facilitates to identify the potential source regions or determine the relative significance of source regions contributing to pollutants at the receptor site (Seibert et al. 1994; Stohl 1996; Hsu et al. 2003). It has been used to provide the spatial pattern of potential sources of $\mathrm{Hg}$ (Cheng et al. 2013), Pb (Chandra et al. 2014), aerosol optical depth (AOD) (Beegum et al. 2012), organic carbon/elemental carbon (OC/EC) (Singh et al. 2016) and trace metals (Chandra et al. 2017) at the receptor sites.

In this technique, each grid cell gets a weighted value obtained by averaging the concentration measured at the receptor site as the associated trajectory crosses the grid cell as follows:

$$
C_{i j}=\frac{1}{\sum_{l=1}^{M} \tau_{i j l}} \sum_{l=1}^{M} C_{l} \tau_{i j l},
$$

where $C_{i j}$ is the average weighted concentration of species in the grid cell $(i, j), l$ is the index of the trajectory, $M$ is the total number of trajectories, $C_{l}$ is the concentration observed at the receptor site on the arrival of trajectory $l$ and $\tau_{i j l}$ is the residence time of trajectory $l$ in the grid cell $(i, j)$. 

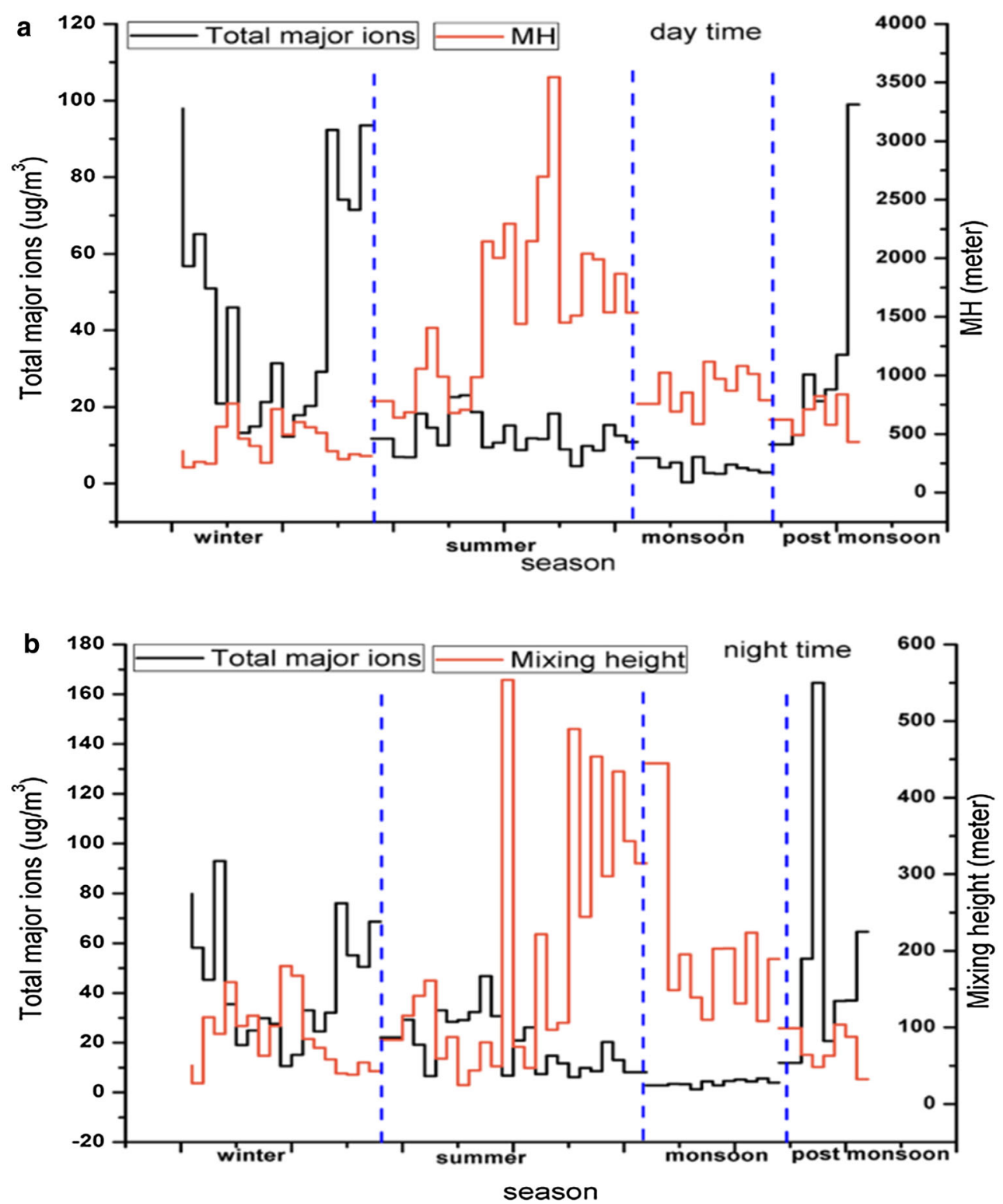

Figure 2. Variation of $\sum$ major ions vs. mixing height during daytime and night-time.

\section{Results and discussion}

\subsection{Variation of major ionic species during daytime and night-time}

The annual mean concentrations of major ionic species followed the order $\mathrm{SO}_{4}^{2-}>\mathrm{NO}_{3}^{-}>$ $\mathrm{Ca}^{2+}>\mathrm{K}^{+}>\mathrm{NH}_{4}^{+}>\mathrm{Mg}^{2+}$ during daytime, while $\mathrm{SO}_{4}^{2-}>\mathrm{NO}_{3}^{-}>\mathrm{K}^{+}>\mathrm{NH}_{4}^{+}>\mathrm{Ca}^{2+}>$ $\mathrm{Mg}^{2+}$ in night-time (figure 3a). Among all the analysed ionic species, the annual mean concentration of $\mathrm{SO}_{4}^{2-}$ had the highest fraction contributing $\sim 46 \%$ to the total major ions $\left(25.8 \mu \mathrm{g} / \mathrm{m}^{3}\right)$ while $\mathrm{NO}_{3}^{-}$and $\mathrm{NH}_{4}^{+}$contributed $33 \%$ and $7 \%$, respectively (Supplementary table $\mathrm{S} 1$ ). On an average, $\mathrm{SO}_{4}^{2-}, \mathrm{NH}_{4}^{+}$and $\mathrm{NO}_{3}^{-}$together contributed $\sim 85 \%$ to total major ions indicating the dominance of secondary aerosols. Xiao et al. (2014) also reported the secondary sulphate as the main source of $\mathrm{PM}_{2.5}$ $(23 \%)$, followed by secondary nitrate $(16 \%)$ in Baoji, China. The high fractional contribution of $\mathrm{SO}_{4}^{2-}$ and $\mathrm{NO}_{3}^{-}$to total major ions suggested that the large amount of $\mathrm{SO}_{2}$ and $\mathrm{NO}_{2}$ is oxidised forming $\mathrm{SO}_{4}^{2-}$ and $\mathrm{NO}_{3}^{-}$aerosols, respectively, which further react with $\mathrm{NH}_{3}$ possibly forming $\left(\mathrm{NH}_{4}\right)_{2} \mathrm{SO}_{4}, \mathrm{NH}_{4} \mathrm{NO}_{3}$ and $\mathrm{NH}_{4} \mathrm{HSO}_{4}$ (FinlaysonPitts and Pitts 2000). The loss of ammonium happens due to many factors affecting the equilibrium gas-particle partitioning in the atmosphere e.g., the extent of changes in diurnal temperature and relative humidity can strongly influence the equilibrium. In addition, the changes in the 

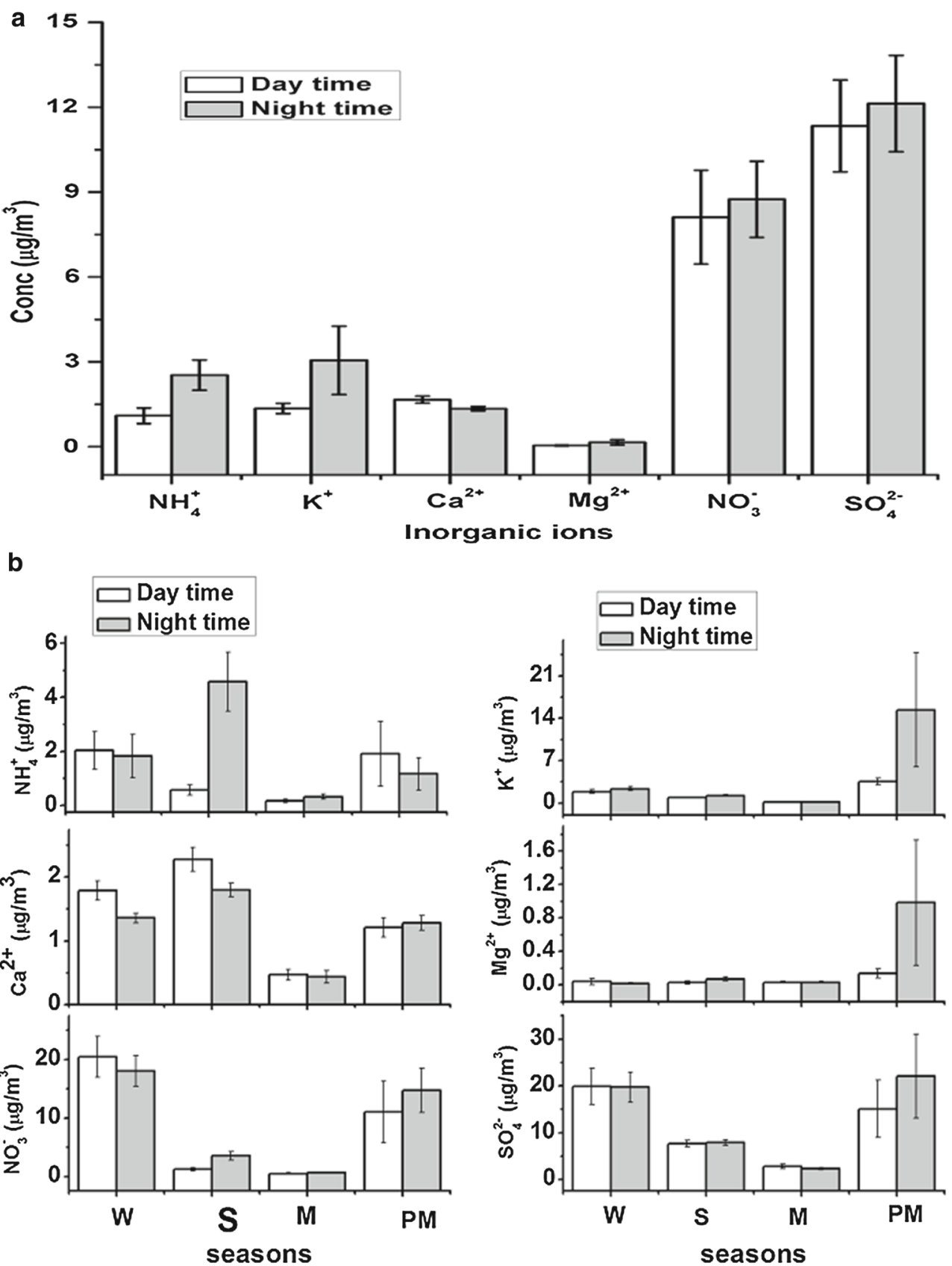

Figure 3. (a) Daytime and night-time concentrations of major ionic species for annual mean and (b) during different seasons (W: winter; S: summer; M: monsoon; PM: post-monsoon).

composition of air mass during sample collection also affect the level of resulting sampling artefacts. Further, the possibility of ammonia loss from the sampling filter is also influenced by the composition of collected aerosol particles (Bassett and Seinfeld 1983; Yuc et al. 2006).

The $\mathrm{SO}_{2}$ and $\mathrm{NO}_{2}$ are primarily contributed by automobiles and industries. However, a significant amount of $\mathrm{SO}_{2}$ and $\mathrm{NO}_{2}$ is also contributed by brick kilns located in the nearby western part of Uttar Pradesh. Song et al. (2014) reported the role of $\mathrm{SO}_{2}$ emitted from coal burning in $\mathrm{SO}_{4}^{2-}$ production after the reaction of pre-existing carbonate particles. The sources of $\mathrm{NH}_{3}$ include agriculture, human and animal waste, etc. Small fractions of $\mathrm{SO}_{4}^{2-}, \mathrm{NO}_{3}^{-}$and $\mathrm{NH}_{4}^{+}$are also contributed by agriculture and crop residue burning in Punjab and Haryana. The fine mode dominance of these ions has been reported by other researchers at various sites as shown in table 1 . In these studies also, the ionic species were observed with a significant seasonality, e.g., winter period 


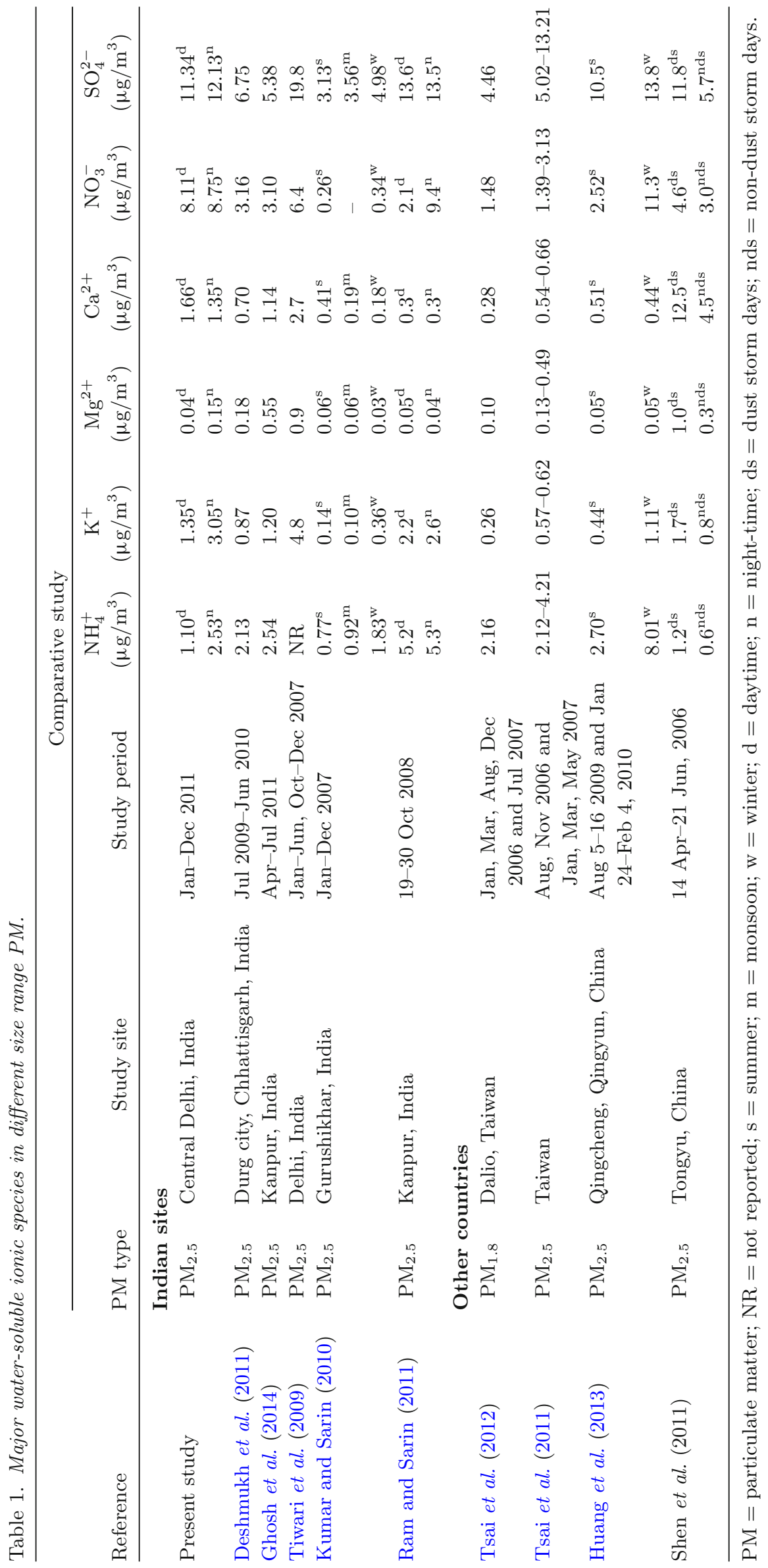


showed higher concentrations of $\mathrm{NO}_{3}^{-}$and $\mathrm{SO}_{4}^{2-}$ as compared to summer. The $\mathrm{Ca}^{2+}$ was observed with slightly higher values during summer than winter (Huang et al. 2013). In addition, the $\mathrm{Ca}^{2+}$ concentration was observed 3 times higher in the dusty period as compared to normal days (Shen et al. 2011). These ionic species also showed a variation along the altitude, IGP regions showed $\sim 2-5$ times higher $\mathrm{SO}_{4}^{2-}$ and $10-20$ times higher $\mathrm{NO}_{3}^{-}$ as compared to mountainous region (Tiwari et al. 2009; Kumar and Sarin 2010; Ram and Sarin 2011; Ghosh et al. 2014). The study on daytime and night-time variability of secondary ions showed a higher concentration of $\mathrm{NO}_{3}^{-}$in night-time as compared to daytime while in case of $\mathrm{SO}_{4}^{2-}$ and $\mathrm{NH}_{4}^{+}$ ions, daytime and night-time concentrations were almost comparable (Ram and Sarin 2011). Another study at Durg city showed the mass concentration of $\mathrm{NO}_{3}^{-}, \mathrm{SO}_{4}^{2-}$ and $\mathrm{NH}_{4}^{+}$as 3.16, 6.75 and $2.13 \mu \mathrm{g} / \mathrm{m}^{3}$, respectively, in fine particles (Deshmukh et al. 2011). Similarly, among secondary ions, the highest concentration was observed for $\mathrm{SO}_{4}^{2-}$ followed by $\mathrm{NO}_{3}^{-}$and $\mathrm{NH}_{4}^{+}$at a location in the IGP region (Ghosh et al. 2014).

Figure 3(b) shows the seasonal mean concentrations of major ionic species during daytime and night-time. The variation in mean concentrations of major ionic species between different seasons was observed to be significantly high. A sharp rise in both daytime and night-time concentrations of most of the major ions was observed during postmonsoon. The winter was observed with slightly higher concentrations during daytime and nighttime for $\mathrm{Ca}^{2+}, \mathrm{NH}_{4}^{+}, \mathrm{Mg}^{2+}$ and $\mathrm{SO}_{4}^{2-}$ except $\mathrm{K}^{+}$. The $\mathrm{NH}_{4}^{+}$showed higher levels during daytime of winter and post-monsoon. The $\mathrm{NH}_{4}^{+}$concentration was found to be 1.7 times higher in daytime than night-time during the post-monsoon. While $\mathrm{NH}_{4}^{+}$had 11.5 and 3.7 times higher concentrations during post-monsoon as compared to monsoon for daytime and night-time, respectively. $\mathrm{K}^{+}$showed significantly high concentrations ( $\sim 4.4$ times) in the night-time as compared to daytime during the post-monsoon.

The daytime and night-time concentrations of $\mathrm{NO}_{3}^{-}$were recorded as higher in winter (20.5 and $18.0 \mu \mathrm{g} / \mathrm{m}^{3}$ ) than post-monsoon (11.0 and 14.8 $\left.\mu \mathrm{g} / \mathrm{m}^{3}\right)$. The rise in $\mathrm{NO}_{3}^{-}$concentration during the post-monsoon might be attributed to lower ambient temperature which reduces the volatilisation of $\mathrm{NO}_{3}^{-}$(Seinfeld and Pandis 1998; Kulshrestha et al. 2009b). The $\mathrm{NO}_{3}^{-}$showed 22.6 and 23.2 times higher concentrations during the post-monsoon than monsoon for daytime and night-time, respectively. The $\mathrm{NO}_{3}^{-}$and $\mathrm{SO}_{4}^{2-}$ were also found to be with 1.3 and 1.5 times higher concentrations, respectively, in night-time during the post-monsoon. The concentrations of $\mathrm{SO}_{4}^{2-}$ were observed as 5.5 and 9.8 times higher for daytime and night-time during the same period. The $\mathrm{SO}_{4}^{2-}$ was also observed with slightly higher concentration during winter (19.9 and $19.7 \mu \mathrm{g} / \mathrm{m}^{3}$ for daytime and night-time, respectively) than postmonsoon (15.1 and $22.1 \mu \mathrm{g} / \mathrm{m}^{3}$ for daytime and night-time, respectively).

The monthly average concentration of $\mathrm{SO}_{4}^{2-}$ was observed to be the highest during December $\left(32.9 \pm 2.9 \mu \mathrm{g} / \mathrm{m}^{3}\right)$ and the lowest during July $\left(2.3 \pm 0.6 \mu \mathrm{g} / \mathrm{m}^{3}\right)$. The concentration of $\mathrm{NO}_{3}^{-}$ was recorded to be the highest in December $\left(31.4 \pm 2.5 \mu \mathrm{g} / \mathrm{m}^{3}\right)$ and the lowest in May $(0.2 \pm$ $\left.0.2 \mu \mathrm{g} / \mathrm{m}^{3}\right)$. Ram and Sarin (2011) also found very high (up to $90 \%$ of total WSIS) contribution of these three ions $\left(\mathrm{SO}_{4}^{2-}, \mathrm{NO}_{3}^{-}\right.$and $\left.\mathrm{NH}_{4}^{+}\right)$in $\mathrm{PM}_{2.5}$ at Kanpur. Rengarajan et al. (2011) reported $\mathrm{SO}_{4}^{2-}$ as the most abundant among water-soluble inorganic species in $\mathrm{PM}_{2.5}$ at Ahmedabad, western India. The high concentrations of $\mathrm{SO}_{4}^{2-}$ and $\mathrm{NO}_{3}^{-}$ among all water-soluble inorganic ions were also reported in Japan and Spain (Khana et al. 2010; Mirante et al. 2014). A comparative study on different size range aerosols suggested that $\mathrm{SO}_{4}^{2-}$, $\mathrm{NO}_{3}^{-}$and $\mathrm{NH}_{4}^{+}$had a higher contribution in fine mode (Kulshrestha et al. 1998). Kulshrestha et al. (2009b) reported $87 \%$ contribution of these ionic species in $\mathrm{PM}_{10}$ aerosols at Allahabad. The annual mean concentrations of $\mathrm{K}^{+}, \mathrm{Ca}^{2+}$ and $\mathrm{Mg}^{2+}$ were found to be $2.2,1.5$ and $0.1 \mu \mathrm{g} / \mathrm{m}^{3}$, respectively, constituting $\sim 15 \%$ of inorganic species in $\mathrm{PM}_{2.5}$. The cations such as $\mathrm{Ca}^{2+}$ and $\mathrm{Mg}^{2+}$ are of crustal origin while $\mathrm{K}^{+}$is mainly contributed by biomass burning in $\mathrm{PM}_{2.5}$.

\subsection{Ratios of major ionic species during daytime and night-time}

The mass ratios (day/night) of major ions were calculated for different seasons as shown in figure 4(a). The mass ratios varied from 0.12 to 2.27 for all major ions, being maximum for the winter and minimum for the summer. The day/night-time mass ratios for $\mathrm{Ca}^{2+}$ were found to be $>1$ during winter, summer and monsoon seasons suggesting that $\mathrm{Ca}^{2+}$ had higher concentration mostly during daytime as compared to night-time. This might be attributed to the crustal sources due to the 

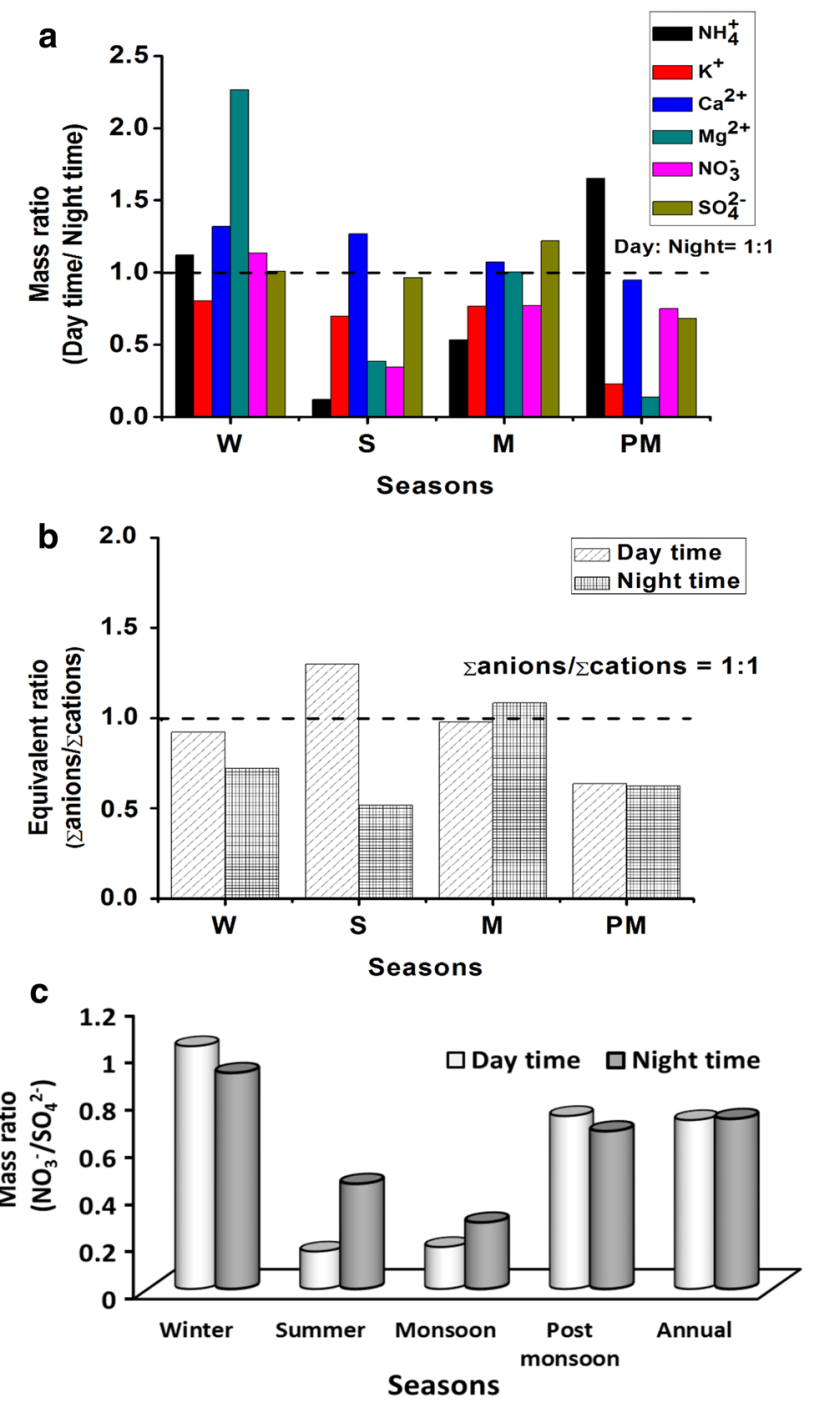

Figure 4. (a) Mass ratio of day vs. night-time concentrations of ionic species for different seasons (W: winter; S: summer; M: monsoon and PM: post-monsoon), (b) equivalent ratio of $\sum$ anions vs. $\sum$ cations and (c) mass ratio of $\mathrm{NO}_{3}^{-} / \mathrm{SO}_{4}^{2-}$ during daytime and night-time of different seasons.

higher suspension of dust from roads, vehicular and construction activities during daytime. Besides this, comparatively high temperature and less relative humidity also add to high loading of crustal aerosols (supplementary figure S1 for temperature and relative humidity).

Furthermore, the equivalent ratios of total anions vs. cations during different seasons were calculated for daytime and night-time. The equivalent ratios were observed as 0.9 and 0.7 in winter during daytime and night-time, respectively. The summer season was observed with equivalent ratios as 1.2 and 0.5 for daytime and night-time, respectively (figure 4b).

\section{$4.3 \mathrm{NO}_{3}^{-}$vs. $\mathrm{SO}_{4}^{2-}$ mass ratios during daytime and night-time}

The mass ratio of $\mathrm{NO}_{3}^{-} / \mathrm{SO}_{4}^{2-}$ can be used as a marker for the relative contribution of mobile $v s$. stationary sources of nitrogen and sulphur species in the atmosphere (Arimoto et al. 1996; Yao et al. 2002; Xiao and Liu 2004; Khoder and Hassan 2008). The mass ratios of $\mathrm{NO}_{3}^{-} / \mathrm{SO}_{4}^{2-}$ with values $>1$ indicate the predominance of mobile sources whereas the mass ratios of $\mathrm{NO}_{3}^{-} / \mathrm{SO}_{4}^{2-}<1$ suggest the dominance of stationary sources (Arimoto et al. 1996). In this study, the annual average mass ratios of $\mathrm{NO}_{3}^{-} / \mathrm{SO}_{4}^{2-}$ in $\mathrm{PM}_{2.5}$ were found to be 0.7 during both daytime and night-time. The mass ratios of $\mathrm{NO}_{3}^{-} / \mathrm{SO}_{4}^{2-}$ were also calculated to observe the dominance of mobile vs. stationary sources during different seasons for daytime and night-time (figure $4 \mathrm{c}$ ). The $\mathrm{NO}_{3}^{-} / \mathrm{SO}_{4}^{2-}$ mass ratios showed a significant variation with the highest values for winter and the least for summer and monsoon seasons. The lower $\mathrm{NO}_{3}^{-} / \mathrm{SO}_{4}^{2-}$ mass ratios during summer and monsoon seasons may be attributed to semi-volatile nature of $\mathrm{NO}_{3}^{-}$due to high temperature. During summer, the $\mathrm{NO}_{3}^{-} / \mathrm{SO}_{4}^{2-}$ mass ratios were observed as 0.16 and 0.45 for daytime and night-time, respectively; while during winter, the $\mathrm{NO}_{3}^{-} / \mathrm{SO}_{4}^{2-}$ mass ratios were observed as 1.02 and 0.91 for daytime and night-time, respectively. Khoder and Hassan (2008) reported $\mathrm{NO}_{3}^{-} / \mathrm{SO}_{4}^{2-}$ mass ratios as 0.41 and 0.34 for weekdays and weekends, respectively. The ratio of $\mathrm{NO}_{3}^{-} / \mathrm{SO}_{4}^{2-}$ with values $<1$ were also reported during weekdays at various sites (Fang et al. 2002; Hu et al. 2002; Yao et al. 2002; Xiao and Liu 2004).

\subsection{Temporal variability of major water-soluble ionic species}

The temporal variability of different ionic species was assessed by calculating the COD between daytime and night-time. The COD is used to reduce the possibility of incorrect assumptions about the heterogeneity of data (Wilson et al. 2005). It provides an accurate assessment of intra-temporal variability using correlation coefficients in conjunction with COD and absolute difference between daytime and night-time concentrations (Wilson et al. 2005).

A total of 118 samples (59 each for daytime and night-time) were taken into consideration for the calculation of COD. The lower COD values 


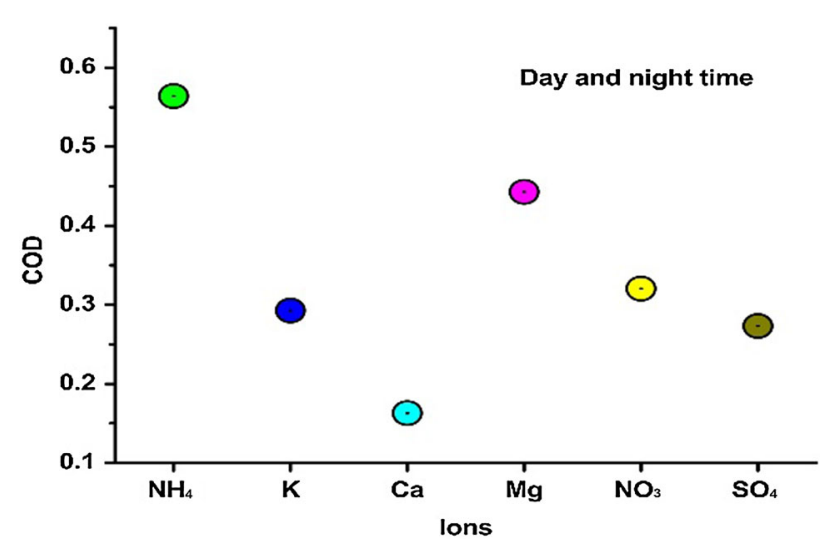

Figure 5. COD analysis for daytime and night-time concentrations of ionic species.

imply similarities between daytime and night-time concentrations while COD values approaching unity indicate vast differences (Krudysz1 et al. 2009). The COD values showed a large variability ranging from 0.56 to 0.16 in this study (figure 5). The highest $\mathrm{COD}_{d n}$ was noticed for $\mathrm{NH}_{4}^{+}(0.56)$ whereas the lowest for $\mathrm{Ca}^{2+}(0.16)$. According to the reports, COD values less than 0.27 shows uniformity between two different factors whereas COD values higher than 0.27 is considered as a high degree of variation (Wilson et al. 2005; Krudysz1 et al. 2009). It is to be noted that the secondary aerosols such as $\mathrm{NH}_{4}^{+}, \mathrm{NO}_{3}^{-}$and $\mathrm{SO}_{4}^{2-}$ showed higher $\mathrm{COD}$ values indicating a significant difference in the sources, chemistry and meteorology during daytime and night-time, respectively.

\subsection{Seasonal variation of major ionic species}

A significant seasonal variation was observed for major ionic species (Supplementary tables S2-S5). Both $\mathrm{NO}_{3}^{-}$and $\mathrm{SO}_{4}^{2-}$ concentrations showed a similar seasonal variation in the order winter $>$ post-monsoon $>$ summer $>$ monsoon. The $\mathrm{NH}_{4}^{+}$ and $\mathrm{Ca}^{2+}$ were also observed with a seasonal variation which followed the order summer $>$ winter $>$ post-monsoon $>$ monsoon. The $\mathrm{K}^{+}$exhibited about 65 times increase in its concentration during the post-monsoon than monsoon. $\mathrm{NO}_{3}^{-}$was also observed with a significant increase (23 times) during the same period. The significant seasonal increase of $\mathrm{K}^{+}$reveals the contribution of largescale biomass crop residue burning in the NW direction, which is also supported by backward trajectory analysis. The $\mathrm{SO}_{4}^{2-}$ had the highest concentration among all the major ions during all seasons. The major contribution of $\mathrm{SO}_{4}^{2-}$ in fine mode was also reported by Kumar and Sarin (2010). The $\mathrm{SO}_{4}^{2-}$ concentrations during the winter and summer seasons were found as 19.8 and $7.8 \mu \mathrm{g} / \mathrm{m}^{3}$, respectively. Similar observations with higher $\mathrm{SO}_{4}^{2-}$ concentrations $\left(13.8 \mu \mathrm{g} / \mathrm{m}^{3}\right)$ during winter than summer $\left(10.5 \mu \mathrm{g} / \mathrm{m}^{3}\right)$ were reported at an industrial site in China (Huang et al. 2013). However, a study on $\mathrm{PM}_{2.5}$ reported by Tsai et al. (2011) showed a comparable range for $\mathrm{SO}_{4}^{2-}(5.0$ $\left.13.2 \mu \mathrm{g} / \mathrm{m}^{3}\right)$ and $\mathrm{NH}_{4}^{+}\left(2.1-4.2 \mu \mathrm{g} / \mathrm{m}^{3}\right)$ while lesser for $\mathrm{NO}_{3}^{-}\left(1.4-3.1 \mu \mathrm{g} / \mathrm{m}^{3}\right)$ than our study. The concentrations $\mathrm{SO}_{4}^{2-}$ and $\mathrm{NO}_{3}^{-}$were recorded as 2.6 and 8 times higher, respectively, during winter than summer. The higher concentrations during winter might be attributed to calm wind conditions and lower mixing height $(235 \mathrm{~m})$. Karar and Gupta (2006) also suggested an increase in pollution levels due to prevailing low wind conditions. The lower mixing height during winter (approximately $1 / 4$ of the summer season) suppresses the convective mixing thereby enhancing the ambient levels of $\mathrm{NO}_{3}^{-}$and $\mathrm{SO}_{4}^{2-}$. For these two ionic species, the least concentrations were observed during summer which might be attributed to more dilution facilitated by convection due to higher mixing height. These two species have vehicular and industrial as their major sources showing uniform source strength throughout different seasons of the year. Hence, the concentration variation of these two ions is highly influenced with mixing height than the rest of the ions during different seasons of the year. The remaining ionic species $\left(\mathrm{NH}_{4}^{+}, \mathrm{K}^{+}\right.$and $\left.\mathrm{Ca}^{2+}\right)$ are influenced by seasonal activities, e.g., agriculture, biomass burning and crustal re-suspension, respectively. The $\mathrm{Ca}^{2+}$ was found to be the highest during summer due to more active crustal sources, while $\mathrm{K}^{+}$ was the highest during post-monsoon due to more biomass burning in Northern India (Kaskaoutis et al. 2013). Also, emissions of brick kilns located in neighbourhood state Uttar Pradesh might have contributed a significant fraction of these components depending on meteorological conditions (wind speed and wind direction) favouring such transport.

The per cent contribution of major ionic species to the total major ions has been shown in figure 6 . The winter season was observed with the highest concentration $\left(44.7 \mu \mathrm{g} / \mathrm{m}^{3}\right)$ of total ions in $\mathrm{PM}_{2.5}$. Similarly, the post-monsoon season was also observed with relatively high concentrations $\left(44.3 \mu \mathrm{g} / \mathrm{m}^{3}\right)$ of total major ionic species due to 


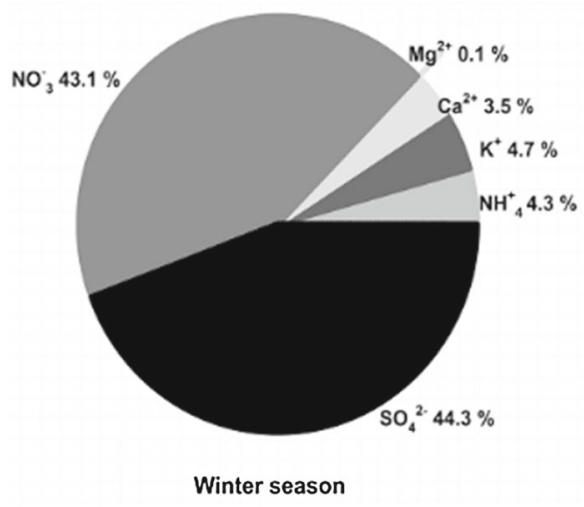

Total ion conc. $44.7 \mu \mathrm{g} / \mathrm{m}^{3}$

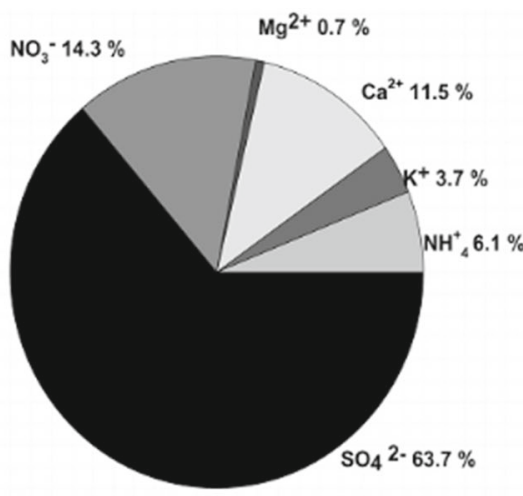

Monsoon season

Total ion conc. $3.9 \mu \mathrm{g} / \mathrm{m}^{3}$
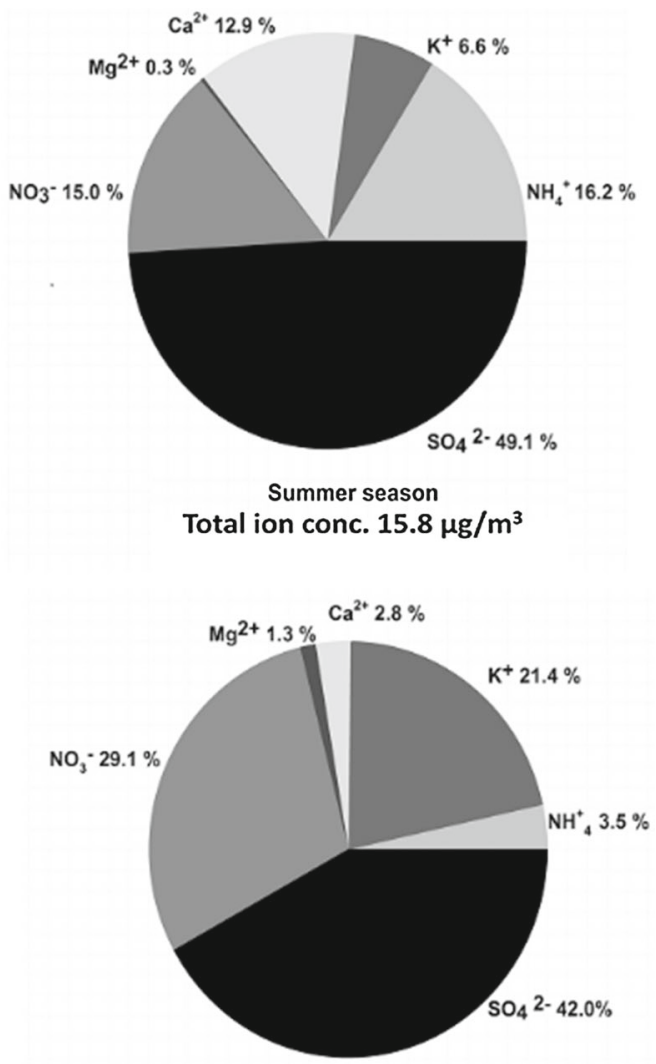

Post monsoon season

Total ion conc. $44.3 \mu \mathrm{g} / \mathrm{m}^{3}$

Figure 6. Fractional contribution (\%) of major ionic species (i.e., $\mathrm{NH}_{4}^{+}, \mathrm{K}^{+}, \mathrm{Mg}^{2+}, \mathrm{Ca}^{2+}$, $\mathrm{NO}_{3}^{-}$and $\mathrm{SO}_{4}^{2-}$ ) to the total studied WSIC during the different seasons.

a significant rise in $\mathrm{K}^{+}$levels ( $\sim 5$ times of winter season). The total major water-soluble ions during the summer and monsoon were recorded as 15.8 and $3.9 \mu \mathrm{g} / \mathrm{m}^{3}$, respectively. The highest mean $\mathrm{K}^{+}$levels during the post-monsoon, whereas the highest concentrations of $\mathrm{NO}_{3}^{-}$and $\mathrm{SO}_{4}^{2-}$ during the winter season were observed (Wang et al. 2006; Kumar et al. 2007). The increased anthropogenic activities (biomass burning) and temperature inversion frequency may contribute to enhanced levels of $\mathrm{K}^{+}$(Rajput et al. 2014). Besides, the backward trajectory analysis reveals that more than $90 \%$ wind advected to the receptor site influenced with Punjab region experiencing large-scale biomass burning during this season enhancing $\mathrm{K}^{+}$ levels (Kaskaoutis et al. 2013). The lowest concentrations of $\mathrm{NO}_{3}^{-}$and $\mathrm{SO}_{4}^{2-}$ during the monsoon period may be due to frequent washout processes and comparatively higher mixing height (about 2.3 times higher than winter). The $\mathrm{NO}_{3}^{-}$levels during summer reduced up to one-eighth of the winter time, whereas $\mathrm{SO}_{4}^{2-}$ reduced up to one-third of the winter time. The increased temperature and low relative humidity during summer might favour volatilisation of $\mathrm{NH}_{4} \mathrm{NO}_{3}$ and reduces the $\mathrm{NO}_{3}^{-}$levels (Seinfeld and Pandis 1998; Kulshrestha et al. 2009b). The $\mathrm{NH}_{4}^{+}$levels were also found to be the lowest during the monsoon season whereas its highest concentration was observed during the summer season. However, the high concentration of $\mathrm{NH}_{4}^{+}$ during summer was observed mainly during nighttime. This may be due to the fact that fields are kept ready during the summer season for sowing of rice during monsoon in Northern India. During this process, a lot of fertilisers and manure are used in the fields contributing to the high concentration of $\mathrm{NH}_{4}^{+}$during night-time.

The $\mathrm{Ca}^{2+}$, a tracer of crustal dust, was found to be the highest during the summer season due to the prevailing high mean temperature, high wind speed resulting in more re-suspension of soil dust and road dust. Han et al. (2015) also 
suggested increased levels of crustal elements during spring (similar to the summer season in India) due to high wind speed. The lowest levels of $\mathrm{Ca}^{2+}$ were observed during the monsoon season when high humidity and rain events minimised the re-suspension of crustal dust. Although very less number of rain events was observed during monsoon, the lowest $\mathrm{Ca}^{2+}$ concentration during monsoon might be attributed to the washout effect which suppresses the re-suspension of crustal components (Kulshrestha et al. 2009c).

Owing to the per cent contribution to total ions, $\mathrm{SO}_{4}^{2-}$ had the highest per cent contribution among all the ions ranging from $41.9 \%$ to $63.7 \%$ for post-monsoon and monsoon seasons, respectively. This is probably due to humidity during the rainy season which facilitates the conversion of $\mathrm{SO}_{2}$ to $\mathrm{SO}_{4}^{2-}$ (Kulshrestha et al. 2009b). $\mathrm{Mg}^{2+}$ contributed the least fraction among all the ions ranging from $0.06 \%$ to $1.26 \%$ for winter and post-monsoon seasons, respectively. The $\mathrm{Ca}^{2+}$ was noticed with the highest percentage during summer, which might be attributed to suitable meteorological conditions for more soil re-suspension and frequent dust storms. The $\mathrm{NO}_{3}^{-}$contributed the highest fraction $(43.1 \%)$ to total ions during winter whereas the least (14.3\%) during monsoon. The sharp decrease in $\mathrm{NO}_{3}^{-}$in summer might be due to volatilisation of $\mathrm{NO}_{3}^{-}$particulates (Seinfeld and Pandis 1998; Kulshrestha et al. 2009b).

An attempt to observe the correlation between $\mathrm{SO}_{4}^{2-}, \mathrm{NO}_{3}^{-}, \mathrm{Ca}^{2+}$ and $\mathrm{NH}_{4}^{+}$has been made, as
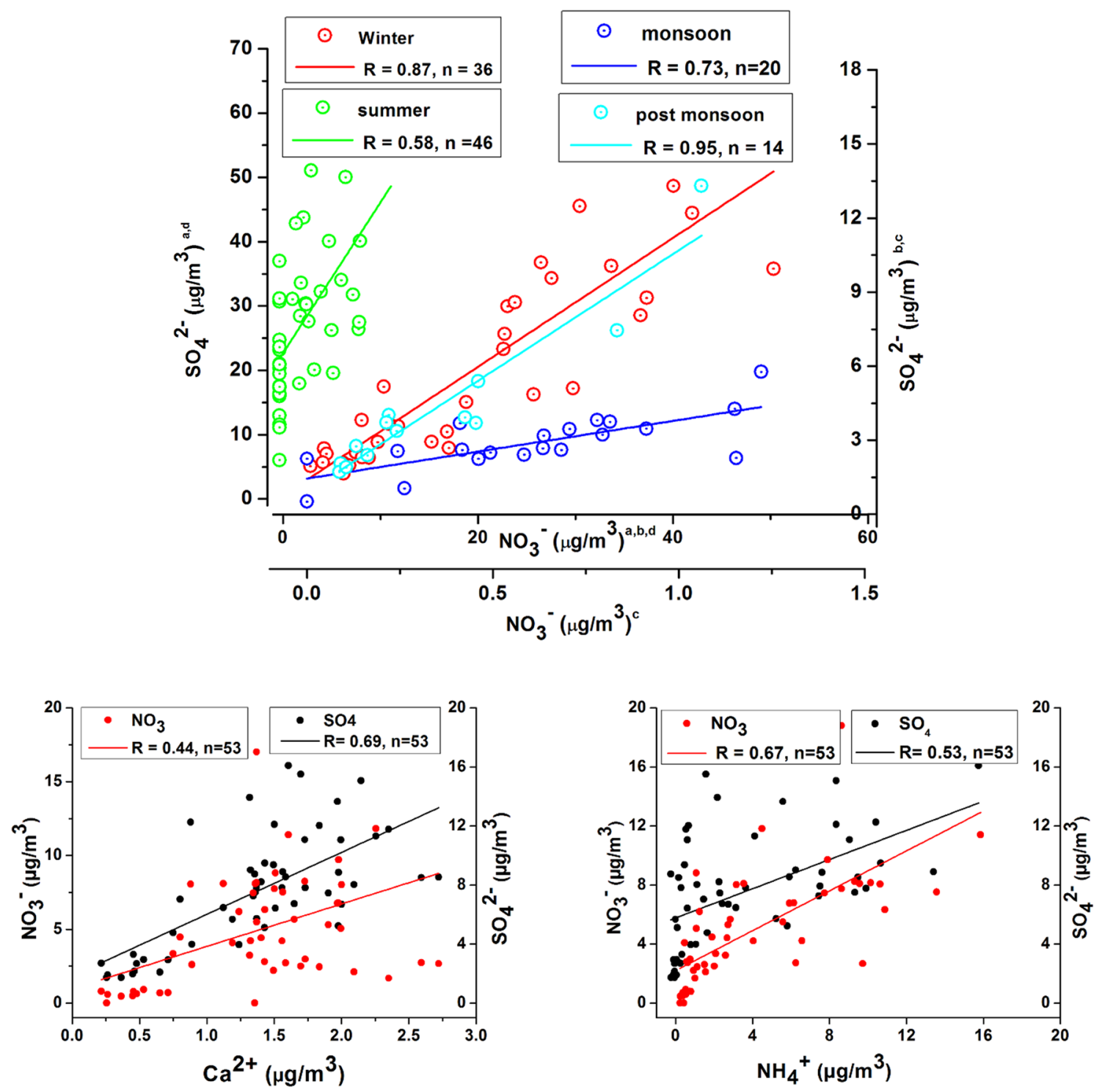

Figure 7. Correlation between $\mathrm{NO}_{3}^{-}$and $\mathrm{SO}_{4}^{2-}$ during different seasons and correlation of $\mathrm{NH}_{4}^{+}$and $\mathrm{Ca}^{2+}$ with $\mathrm{NO}_{3}^{-}$and $\mathrm{SO}_{4}^{2-}$. 

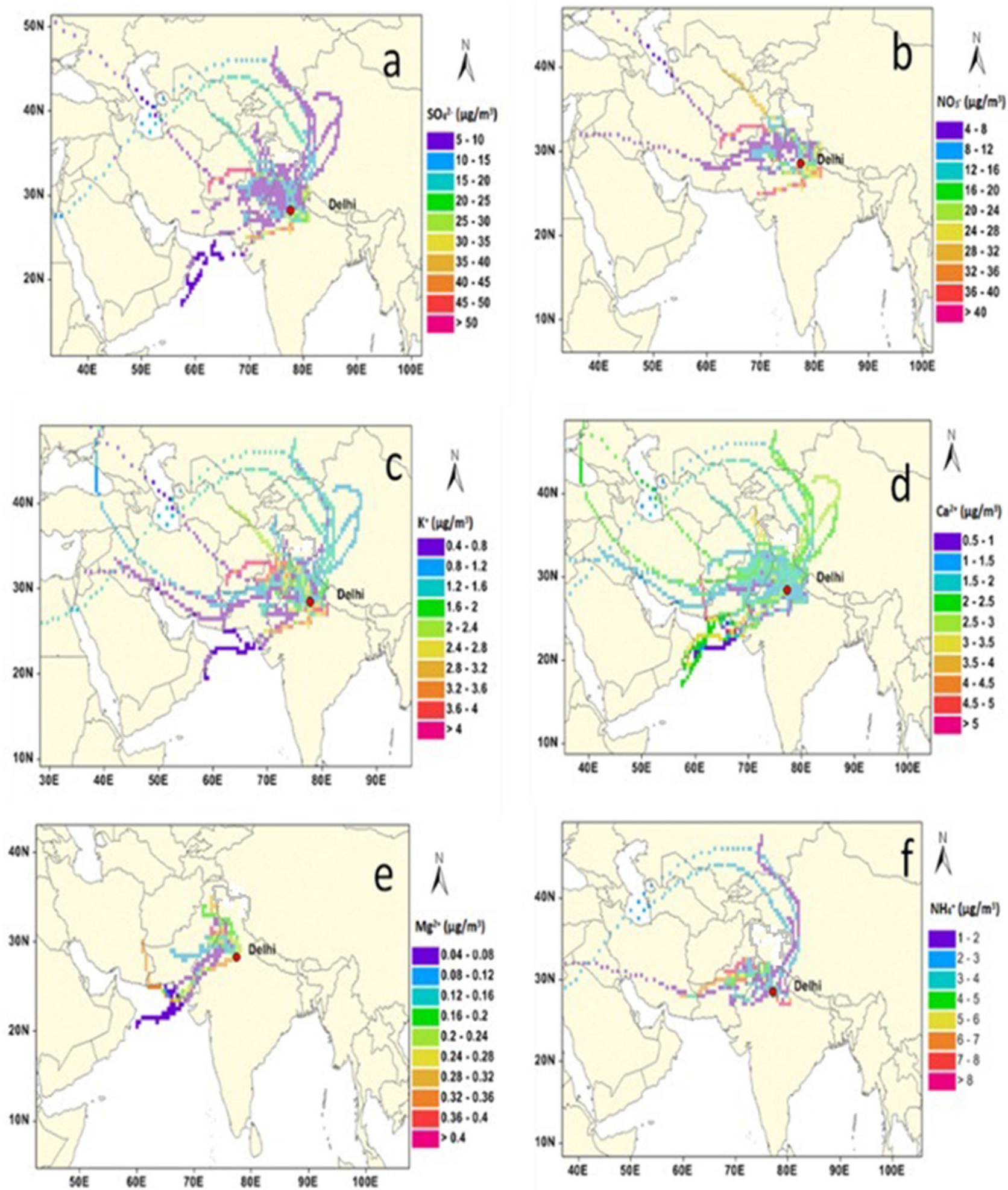

Figure 8. CWT analysis of $\mathrm{SO}_{4}^{2-}, \mathrm{NO}_{3}^{-}, \mathrm{K}^{+}, \mathrm{Ca}^{2+}, \mathrm{Mg}^{2+}$ and $\mathrm{NH}_{4}^{+}$(maps not to scale).

shown in figure 7. The $\mathrm{NO}_{3}^{-}$and $\mathrm{SO}_{4}^{2-}$ showed a good correlation during winter $(r=0.87)$, postmonsoon $(r=0.95)$ and monsoon $(r=0.73)$, whereas a relatively weak correlation during summer $(r=0.58)$. The correlation during winter, post-monsoon and monsoon suggested their emission from common origin influenced by anthropogenic activities. The lowest observed correlation during summer may be due to volatilisation of $\mathrm{NO}_{3}^{-}$. This study found good correlation between $\mathrm{NO}_{3}^{-}$and $\mathrm{NH}_{4}^{+}(r=0.67$ and $n=53)$ which explains that $\mathrm{NO}_{3}^{-}$is mainly neutralised by 
$\mathrm{NH}_{4}^{+}$while $\mathrm{SO}_{4}^{2-}$ showed a moderate correlation with $\mathrm{NH}_{4}^{+}(r=0.53$ and $n=53)$, and significant positive correlation with $\mathrm{Ca}^{2+}(r=0.69$ and $n=$ 53) (Supplementary table S6). The good correlation between $\mathrm{SO}_{4}^{2-}$ and $\mathrm{Ca}^{2+}$ in this study suggested a preferable neutralisation of $\mathrm{SO}_{4}^{2-}$ by mineral dust (Kulshrestha et al. 1998; Ghosh et al. 2014). The neutralisation of acidic constituents by mineral dust has been discussed in detail in an earlier study done by Rastogi and Sarin (2006).

\subsection{CWT analysis}

For CWT analysis, 12 hourly mean concentrations were estimated for each species. Each concentration value was incorporated with one back trajectory corresponding to the same time interval (Wang et al. 2009). The CWT plots for six major water-soluble ions of $\mathrm{PM}_{2.5}$ have been shown in figure 8 . This analysis revealed potential source regions for each species contributing to the receptor site. The major regions were identified as Northern Gangetic plain (western Uttar Pradesh), Thar Desert, eastern states and central Asian countries.

For $\mathrm{NO}_{3}^{-}$, a few trajectories passing over western Uttar Pradesh, Punjab and Central Pakistan were identified as major contributors to the site, while a majority of trajectories were identified with weak or moderate contributions from Northern and South Western Indian states. CWT analysis of $\mathrm{SO}_{4}^{2-}$ revealed that it was contributed from wider regions than $\mathrm{NO}_{3}^{-}$. The potential regions contributing to $\mathrm{SO}_{4}^{2-}$ were the western states including Punjab and Central Pakistan. Few trajectories were found to be originated from the Arabian Sea, central Asia and northern African regions showing weak source strength. On the contrary, Zhang et al. (2014) suggested long-range transport of $\mathrm{SO}_{4}^{2-}$ ion from Eastern China to Northeastern Tibetan Plateau.

The western Uttar Pradesh and Punjab regions were identified as potential contributors of $\mathrm{K}^{+}$ at the receptor site (figure 8). As $\mathrm{K}^{+}$has been reported as a tracer of biomass burning (Nair et al. 2006; Kundu et al. 2010) and hence, it may be attributed to biomass and crop residue burning activities in identified regions.

The CWT analysis for $\mathrm{Ca}^{2+}$ showed that most of the trajectories had a weak potential to the receptor site. A very confined potential region located in the SW direction (the Thar Desert of Rajasthan and Southern Pakistan region) was identified for the transport of $\mathrm{Ca}^{2+}$ to the sampling site. Although $\mathrm{Mg}^{2+}$ levels were found to be insignificant during the study, the CWT analysis for $\mathrm{Mg}^{2+}$ identified Punjab, Central Pakistan and the Thar Desert as major contributors to the receptor site. For $\mathrm{NH}_{4}^{+}$, western UP, Punjab and Central Pakistan were identified as the potential contributors to the receptor site. These regions experience extensive agriculture activities contributing the emissions of $\mathrm{NH}_{4}^{+}$into the atmosphere. However, the long-range transport for $\mathrm{NH}_{4}^{+}$ was identified with weak potential which implies that the CWT analysis for $\mathrm{NH}_{4}^{+}$showed higher grid values for local and regional areas only. A few long-range trajectories with lower grid value were observed. A comprehensive long-term study is needed for further verification of different source regions.

\section{Conclusions}

A comprehensive chemical analysis of primary and secondary inorganic species in $\mathrm{PM}_{2.5}$ was examined in this study to observe their daytime and nighttime variation in Delhi. The chemical components of $\mathrm{PM}_{2.5}$ showed significant seasonal variation due to advection from distant sources. The rise in the ambient level of $\mathrm{SO}_{4}^{2-}$ in winter might be due to less dispersion, prevalent calm wind conditions and shallow boundary layer. Also, emissions from brick kilns in the nearby western part of Uttar Pradesh state also contributed to $\mathrm{SO}_{4}^{2-}$ and $\mathrm{NO}_{3}^{-}$significantly in $\mathrm{PM}_{2.5}$. The maximum concentrations during the post-monsoon for $\mathrm{K}^{+}$might be due to air masses coming from Punjab and Haryana regions having frequent crop residue burning activity during this period. The significant seasonal variation of $\mathrm{K}^{+}$reveals the contribution of large-scale biomass or crop residue burning in the NW direction. The CWT analysis for $\mathrm{Ca}^{2+}$ showed a very confined potential region located in the SW direction (the Thar Desert of Rajasthan and southern Pakistan regions). The CWT analysis for $\mathrm{Mg}^{2+}$ identified Punjab, central Pakistan and the Thar Desert as major contributors to the receptor site. For $\mathrm{NH}_{4}^{+}$, western Uttar Pradesh, Punjab and central Pakistan were identified as the potential contributors to the receptor site. The CWT of $\mathrm{NO}_{3}^{-}$revealed regions of western Uttar Pradesh, Punjab and central Pakistan as major contributors to the site. The potential regions contributing to $\mathrm{SO}_{4}^{2-}$ were the western states including Punjab and Central Pakistan. This study 
suggests that the proper understanding of potential source regions to control the emissions of precursors of secondary inorganic species is important for New Delhi. This will help to improve the air quality in this heavily polluted city of India.

\section{Acknowledgements}

The authors are grateful to the Director, CSIRNPL, for his encouragement and providing facilities to carry out this research work. One of the authors, S Chandra gratefully acknowledge CSIR fellowship. Benefits of scientific discussions with Prof. J J Schauer, University of Wisconsin, Madison, USA and Prof. U C Kulshrestha, Jawaharlal Nehru University, New Delhi, India, are gratefully acknowledged. The authors are thankful to the editor and anonymous reviewers for improving the quality of this paper.

\section{References}

Arimoto R, Duce R A, Savoie D L, Prospero J M, Talbot R, Cullen J D, Tomza U, Lewis N F and Ray B J 1996 Relationships among aerosol constituents from Asia and the North Pacific during Pem-West A; J. Geophys. Res. 101 2011-2023.

Bassett M and Seinfeld J H 1983 Atmospheric equilibrium model of sulfate and nitrate aerosols; Atmos. Environ. 17 2237-2252.

Beegum S N, Moorthy K K, Gogoi M M, Babu S S and Pandey S K 2012 Multi-year investigations of aerosols from an Island station, Port Blair, in the Bay of Bengal: Climatology and source impacts; Ann. Geophys. 30 1113-1127.

Bisht D S, Dumka U C, Kaskaoutis D, Pipal A S, Srivastava A K, Soni V K, Attri S D, Steesh M and Tiwari S 2015 Carbonaceous aerosols and pollutants over Delhi urban environment: Temporal evolution, source apportionment and radiative forcing; Sci. Total Environ. 521-522 431445.

Brown S S, Ryerson T B, Wollny A G, Brock C A, Peltier R, Sullivan A P, Weber R J, Dube W P, Trainer M, Meagher J F, Fehsenfeld F C and Ravishankara A R 2006 Variability in nocturnal nitrogen oxide processing and its role in regional air quality; Science 311 67-70.

Chandra S, Kulshrestha M J and Singh R 2014 Temporal variation and concentration weighted trajectory analysis of lead in $\mathrm{PM}_{10}$ aerosols at a site in central Delhi, India; Int. J. Atmos. Sci. 2014 1-8, https://doi.org/10.1155/ $2014 / 323040$.

Chandra S, Kulshrestha M J, Singh R and Singh N 2017 Chemical characteristics of trace metals in $\mathrm{PM}_{10}$ and their concentrated weighted trajectory analysis at Central Delhi, India; J. Environ. Sci. 55 184-196.

Cheng I, Zhang L, Blanchard P, Dalziel J and Tordon R 2013 Concentrated-weighted trajectory approach to identifying potential sources of speciated atmospheric mercury at an urban coastal site in Nova Scotia, Canada; Atmos. Chem. Phys. 13 6031-6048.

Cheng C, Wang G, Meng J, Wang Q, Cao J, Li J and Wang J 2015 Size-resolved airborne particulate oxalic and related secondary organic aerosol species in the urban atmosphere of Chengdu, China; Atmos. Res. 161-162 134142 .

Cheung H C, Wang T, Baumann K and Guo H 2005 Influence of regional pollution outflow on the concentrations of fine particulate matter and visibility in the coastal area of southern China; Atmos. Environ. 39 6463-6474.

Dall'Osto M, Harrison R M, Coe H and Williams P 2009 Real-time secondary aerosol formation during a Fog event in London; Atmos. Chem. Phys. 9 2459-2469.

Deshmukh D K, Deb M K and Verma S K 2010 Distribution patterns of coarse, fine and ultrafine atmospheric aerosol particulate matters in major cities of Chhattisgarh; Indian J. Environ. Protection 30 184-197.

Deshmukh D K, Deb M K, Tsai Y I and Mkoma S L 2011 Water soluble ions in $\mathrm{PM}_{2.5}$ and $\mathrm{PM}_{1}$ aerosols in Durg city, Chhattisgarh, India, India; Aerosol Air Qual. Res. 11 696-708.

Echalar F, Artaxo P and Martins J V 1998 Long-term monitoring of atmospheric aerosols in the Amazon Basin' Source identification and apportionment; J. Geophys. Res. 103 31849-31864.

Fang G, Chang C, Wu Y and Fu P P 2002 Ambient suspended particulate matters and related chemical species study in central Taiwan, Taichung during 1998-2001; Atmos. Environ. 36 1921-1928.

Finlayson-Pitts B J and Pitts Jr J N 2000 Chemistry of the Upper and Lower Atmosphere; Academic Press, San Diego, CA, USA.

Ghosh S, Gupta T, Rastogi N, Gaur A, Misra A, Tripathi S N, Paul D, Tare V, Prakash O, Bhattu D, Dwivedi A K, Kaul D S, Dalai R and Mishra S K 2014 Chemical characterization of summer time dust events at Kanpur: Insight into the sources and level of mixing with anthropogenic emissions; Aerosol Air Qual. Res. 14 879-891.

Guo S, Hu M, Wang Z B, Slanina J and Zhao Y L 2010 Size-resolved aerosol water soluble ionic compositions in the summer of Beijing: Implication of regional secondary formation; Atmos. Chem. Phys. 10 947-959.

Han Y J, Kim H W, Cho S H, Kim P R and Kim W J 2015 Metallic elements in $\mathrm{PM}_{2.5}$ in different functional areas of Korea: Concentrations and source identification; Atmos. Res. 153 416-428.

Hong Y M, Lee B K, Park K J, Kang M H, Jung Y R, Lee D S and Kim M G 2002 Atmospheric nitrogen and sulphur containing compounds for three sites of south Korea; Atmos. Environ. 36 3485-3494.

Hsu Y K, Holsen T M and Hopke P K 2003 Comparison of hybrid receptor models to locate PCB sources in Chicago; Atmos. Environ. 37 545-562.

Hu M, He L, Zhang Y, Wang M, Kim Y P and Moon K C 2002 Seasonal variation of ionic species in fine particles at Qingdao, China; Atmos. Environ. 36 5853-5859.

Huang B, Liu M, Ren Z, Bi X, Zhang G, Sheng G and Fu J 2013 Chemical composition, diurnal variation and sources of $\mathrm{PM}_{2.5}$ at two industrial sites of South China; Atmos. Pollut. Res. 4 298-305. 
Intergovernmental Panel on Climate Change (IPCC) 2007 IPCC Fourth Assessment Report; Cambridge University Press, London.

Jonathan L B, Neil L R and Xuezhu L 1997 A continuous, high resolution record of urban airborne particulates suitable for retrospective microscopical analysis; Atmos. Environ. 31 171-181.

Karageorgos E T and Rapsomanikis S 2007 Chemical characterization of the inorganic fraction of aerosols and mechanisms of the neutralization of atmospheric acidity in Athens, Greece; Atmos. Chem. Phys. 7 3015-3033.

Karar K and Gupta A K 2006 Seasonal variations and chemical characterization of ambient $\mathrm{PM}_{10}$ at residential and industrial sites of an urban region of Kolkata (Calcutta), India; Atmos. Res. 81 36-53.

Kaskaoutis D G, Kumar S, Sharma D, Singh R P, Kharol S K, Sharma M, Singh A K, Singh S, Singh A and Singh D 2013 Effects of crop residue burning on aerosol properties, plume characteristics, and long-range transport over northern India; J. Geophys. Res: Atmos., https://doi.org/ 10.1002/2013JD021357.

Kesavachandran C N, Kamal R, Bihari V, Pathak M K and Singh A 2015 Particulate matter in ambient air and its association with alterations in lung functions and respiratory health problems among outdoor exercisers in National Capital Region, India; Atmos. Pollut. Res. 6 618-625.

Khana M F, Shirasuna Y, Hirano K and Masunaga S 2010 Characterization of $\mathrm{PM}_{2.5}, \mathrm{PM}_{2.5-10}$ and $\mathrm{PM}_{>10}$ in ambient air, Yokohama, Japan; Atmos. Res. 96 159-172.

Khoder M I and Hassan S K 2008 Weekday/weekend differences in ambient aerosol level and chemical characteristics of water-soluble components in the city centre; Atmos. Environ. 42 7483-7493.

Kim E, Hopke P K and Edgerton E S 2003 Source identification of atlanta aerosol by positive matrix factorization; J. Air Waste Manage. Assoc. 53 731-739.

Krudysz1 M, Moore K, Geller M, Sioutas C and Froines C 2009 Intra-community spatial variability of particulate matter size distributions in Southern California/Los Angeles; Atmos. Chem. Phys. 9 1061-1075.

Kulshrestha U C, Saxena A, Kumar N, Kumari K M and Srivastava S S 1998 Chemical composition and association of size-differentiated aerosols at a suburban site in a semiarid tract of India; J. Atmos. Chem. 29 109-118.

Kulshrestha A, Bisht D S, Masih J, Massey D, Tiwari S and Taneja A 2009a Chemical characterization of watersoluble aerosols in different residential environments of semi-arid region of India; J. Atmos. Chem. 62 121-138.

Kulshrestha U C, Raman R S, Kulshrestha M J, Rao T N and Hazarika P J 2009b Secondary aerosol formation and identification of regional source locations by PSCF analysis in the Indo-Gangetic region of India; J. Atmos. Chem. 63 $33-47$.

Kulshrestha U C, Reddy L A K, Satyanarayana J and Kulshrestha M J 2009c Real-time wet scavenging of major chemical constituents of aerosols and role of rain intensity in Indian region; Atmos. Environ. 43 5123-5127.

Kumar A and Sarin M M 2009 Mineral aerosols from western India: Temporal variability of coarse and fine atmospheric dust and elemental characteristics; Atmos. Environ. 43 4005-4013.
Kumar A and Sarin M M 2010 Atmospheric water-soluble constituents in fine and coarse mode aerosols from highaltitude site in western India: Long-range transport and seasonal variability; Atmos. Environ. 44 1245-1254.

Kumar R, Srivastava S S and Kumari K M 2007 Characteristics of aerosols over urban and suburban site of semiarid region in India: Seasonal and spatial variations; Aerosol Air Qual. Res. 7 531-549.

Kumar S, Aggarwal S G, Gupta P K and Kawamura K 2015 Investigation of the tracers for plastic-enriched waste burning aerosols; Atmos. Environ. 108 49-58.

Kundu S, Kawamura K, Andreae T W, Hoffer A and Andreae M O 2010 Molecular distributions of dicarboxylic acids, ketocarboxylic acids and a dicarbonyls in biomass burning aerosols: Implications for photochemical production and degradation in smoke layers; Atmos. Chem. Phys. 10 2209-2225.

Lee Y L and Sequeira R 2002 Water-soluble aerosol and visibility degradation in Hong Kong during autumn and early winter, 1998; Environ. Pollut. 116 225-233.

Malm W C, Molenar J V, Eldred R A and Sisler J F 1996 Examining the relationship among atmospheric aerosols and light scattering and extinction in the Grand Canyon area; J. Geophys. Res. 101(14) 19251--19265.

Mirante F, Salvador P, Pio C, Alves C, Artiñano B, Caseiro A and Revuelta M A 2014 Size fractionated aerosol composition at roadside and background environments in the Madrid urban atmosphere; Atmos. Res. 138 278-292.

Miyazaki Y, Aggarwal S G, Singh K, Gupta P K and Kawamura K 2009 Dicarboxylic acids and water-soluble organic carbon in aerosols in New Delhi, India, in winter: Characteristics and formation processes; J. Geophys. Res. 114 D19206, https://doi.org/10.1029/2009JD011790.

Nair P R, George S K, Sunilkumar S V, Parameswaran K, Jocab S and Abraham A 2006 Chemical composition of aerosol over peninsular India during winter; Atmos. Environ. 40 6477-6493.

Pitts B J F and Pitts J N 1986 Atmospheric chemistry: Fundamentals and experimental techniques; A WileyInterscience Publication, New York.

Pope C A 2000 Review: Epidemiological basis for particulate air pollution health standards; Aerosol Sci. Technol. 32 4-14.

Ragosta M, Caggiano R, Macchiato M, Sabia S and Trippetta S 2008 Trace elements in daily collected aerosol: Level characterization and source identification in a fouryear study; Atmos. Res. 89 206-217.

Rajput P, Sarin M M, Sharma D and Singh D 2014 Characteristics and emission budget of carbonaceous species from post-harvest agricultural-waste burning in source region of the Indo-Gangetic Plain; Tellus B 66 21026, https://doi. org/10.3402/tellusb.v66.21026.

Ram K and Sarin M M 2011 Day-night variability of EC, OC, WSOC and inorganic ions in urban environment of Indo-Gangetic Plain: Implications to secondary aerosol formation; Atmos. Environ. 45 460-468.

Rastogi N and Sarin M M 2006 Chemistry of aerosols over a semi-arid region: Evidence for acid neutralization by mineral dust; Geophys. Res. Lett. 33 L2 3815, https:// doi.org/10.1029/2006GL027708.

Rengarajan R, Sudheer A K and Sarin M M 2011 Wintertime $\mathrm{PM}_{2.5}$ and $\mathrm{PM}_{10}$ carbonaceous and inorganic constituents 
from urban site in western India; Atmos. Res. 102(4) 420-431.

Righi M J, Hendricks J and Sausen R 2013 The global impact of the transport sectors on atmospheric aerosol: Simulations for year 2000 emissions. Atmos. Chem. Phys. 13 9939-9970.

Seibert P, Kromp-Kolb H, Baltensperger U, Jost D T and Schwikowski M 1994 Trajectory analysis of high-alpine air pollution data; In: Air Pollution Modelling and its Application (eds) Gryning S-E and Millan M M, Plenum Press, New York, Vol. X, pp. 595-596.

Seinfeld J H and Pandis S N 1998 Atmospheric chemistry and physics; Wiley, New York.

Shen Z, Wang X, Zhang R, Ho K, Cao J and Zhang M 2011 Chemical composition of water-soluble ions and carbonate estimation in spring aerosol at a semiarid site of Tongyu, China; Aerosol Air Qual. Res. 11 360-368.

Singh R, Kulshrestha M J, Kumar B and Chandra S 2016 Impact of anthropogenic emissions and open biomass burning on carbonaceous aerosols in Urban and Rural Environments of Indo-Gangetic Plain; Air Qual. Atmos. Health 9 809-822.

Song X, Shao L, Zheng Q and Yang S 2014 Mineralogical and geochemical composition of particulate Matter $\left(\mathrm{PM}_{10}\right)$ in coal and non-coal industrial cities of Henan Province, North China; Atmos. Res. 143 462472 .

Srivastava A K, Bisht D S, Ram K, Tiwari S and Srivastava M K 2014 Characterization of carbonaceous aerosols over Delhi in Ganga basin: Seasonal variability and possible sources; Environ. Sci. Pollut. Res. Inter. 21 86108619.

Stohl A 1996 Trajectory statistics - A new method to establish source-receptor relationship of air pollutants and its application to the transport of particulate sulfate in Europe; Atmos. Environ. 30 579-587.

Tiwari S, Srivastava A K, Bisht D S, Bano T, Singh S, Behura S, Srivastava A K, Chate D M and Padmanabhamurty B 2009 Black carbon and chemical characteristics of $\mathrm{PM}_{10}$ and $\mathrm{PM}_{2.5}$ at an urban site of North India; J. Atmos. Chem. 62 193-209.

Tsai H H, Yuan C S, Hung C H and Lin C 2011 Physicochemical properties of $\mathrm{PM}_{2.5}$ and $\mathrm{PM}_{2.5-10}$ at Inland and offshore sites over southeastern coastal region of Taiwan Strait; Aerosol Air Qual. Res. 11 664-678.

Tsai J H, Lin J H, Yao Y C and Chiang H L 2012 Size distribution and water soluble ions of ambient particulate matter on episode and non-episode days in southern Taiwan; Aerosol Air Qual. Res. 12 263-274.

Utsunomiya A and Shinji W 1996 Temperature and humidity dependence on aerosol composition in the northern Kyushu, Japan; Atmos. Environ. 30 2379-2386.

Wang Y, Zhuang G, Zhang X, Huang K, Xu C, Tang A, Chen $\mathrm{J}$ and An Z 2006 The ion chemistry, seasonal cycle, and sources of $\mathrm{PM}_{2.5}$ and TSP aerosol in Shanghai; Atmos. Environ. textbf40 2935-2952.

Wang Y Q, Zhang X Y and Draxler R R 2009 Traj stat GIS-based software that uses various trajectory statistical analysis methods to identify potential sources from long term air pollution measurement data; Environ. Model. Soft. 24(8) 938-939.

WHO (World Health Organization) 2014 Ambient (outdoor) air pollution database (2014). http://www.who.int/phe/ health_topics/outdoorair/databases/cities/en/.

Wilson J G, Kinghama S, Pearce J and Sturman A P 2005 A review of intra-urban variations in particulate air pollution: Implications for epidemiological research; Atmos. Environ. 39 6444-6462.

Xiao H and Liu C 2004 Chemical characteristics of water soluble components in TSP over Guiyang, SW China, 2003; Atmos. Environ. 38 6297-6306.

Xiao S, Wang Q Y, Cao J J, Huang R J, Chen W D, Han Y M, Xu H M, Liu S X, Zhou Y Q, Wang P, Zhang J and Zhan C L 2014 Long-term trends in visibility and impacts of aerosol composition on visibility impairment in Baoji, China; Atmos. Res. 149 88-95.

Yao X, Chan C K, Fang M, Cadle S, Chan T, Mulawa P, He K and Ye B 2002 The water-soluble ionic composition of $\mathrm{PM}_{2.5}$ in Shanghai and Beijing, China; Atmos. Environ. 36 4223-4234.

Yuc X-Y, Leea T, Ayresa B, Kreidenweisa S M, Malmb W and Collett Jra L J 2006 Loss of fine particle ammonium from denuded nylon filters; Atmos. Environ. $404797-$ 4807.

Zhang Q, Zhang J and Xue H 2010 The challenge of improving visibility in Beijing; Atmos. Chem. Phys. Discuss. 10 6199-6218.

Zhang N, Cao J, Liu S, Zhao Z, Xu H and Xiao S 2014 Chemical composition and sources of $\mathrm{PM}_{2.5}$ and TSP collected at Qinghai Lake during summer time; Atmos. Res. 138 213-222.

http://www.arl.noaa.gov/ready/hysplit4.html.

http://www.meteothinker.com/Documents/Wang_Trajstat_ Manuscript.pdf. 